\title{
FACTORS AFFECTING FARM AND NON-FARM INCOME OF HAOR INHABITANTS OF BANGLADESH
}

\author{
M. T. Parvin' ${ }^{1}$ and M. Akteruzzaman ${ }^{2}$ \\ Department of Agricultural Economics, Bangladesh Agricultural University \\ Mymensingh-2202, Bangladesh
}

\begin{abstract}
The study has been conducted to examine the factors influencing farm and nonfarm income of Haor economy in Bangladesh. Dingaputa Haor area of Netrokona district was selected for the present study and a sample of 60 farmers had been taken randomly. The log linear form of Cobb-Douglas production function was chosen to determine the effects of socioeconomic variables on farm income and non-farm income. Apart from this, some descriptive statistical analysis were done to examine the socioeconomic characteristics of sampled households. The estimated results of the regression models revealed that family size and farm size had a significant positive effect on farm income and non-farm income had a significant negative effect on farm income. On the other hand, family size had a positive and significant effect on non-farm income and farm income had a negative and significant effect on non-farm income. To promote the farm and non-farm sector income and strengthening its potential linkages between them, the study mainly recommends increasing efforts on two fronts: first, reforming the institutions responsible for rural development and second, development activities and projects that would enhance farm and non-farm income and the linkages between them.
\end{abstract}

Key Words: Farm income, Non farm income, Haor

\section{INTRODUCTION}

The economy of Bangladesh largely depends on agriculture and it is the principal occupation of the rural people. The overall economic growth mostly depends on agriculture as well as farm activities. The Government has identified agriculture and rural development as the topmost priority sector for rapid poverty reduction. The rural economy as a whole contributes more than $56 \%$ of total GDP where the contribution of rural non-farm sector is $36.71 \%$ (BER, 2011). Agriculture generates $48.4 \%$ of total employment, contributes a quarter of total export earnings and provides food security for the increasing population (Islam, 2012).

1 Ex-M. S. Student and 2Professor, Department of Agricultural Economics, Bangladesh Agricultural University, Mymensingh-2202, Bangladesh 
The haor basin located in the north-eastern region of Bangladesh is a wetlands ecosystem considered to be of international ecological importance due to the extensive waterfowl population that uses the basin as its habitat. There are altogether 423 small and large haors in Bangladesh (Alam et al., 2011) comprising an area of about $8000 \mathrm{~km}^{2}$ dispersed in the districts of Sunamgonj, Sylhet, Moulvibazar, Hobigonj, Netrokona and Kishoreganj (BHWDB Report, 2011).

Despite the economic importance of the Haors, people in the region are poorer than any other parts of the country. More than $28 \%$ of the total population here lives below the lower poverty line (BHWDB Report, 2011). Natural disasters are the main reason of poverty, which is aggravated by lack of availability of basic infrastructure and social amenities, inequity in resources acquisition and poor access to natural resources. Development potentials are huge, but need an integrated approach for maximizing the utilization of resources, both human and natural resources (BHWDB Report, 2011). Almost $80 \%$ of this area (i.e. 0.68 million ha) is covered by Boro rice, while only about $10 \%$ area is covered by T. Aman production (Alam et al., 2011).

Farm means a production unit where rational use of resources is made. It is a place or portion of earth's surface on which a particular farmer, farm family or other organizations cultivates crops or tends livestock. It may be owned and operated by a single individual, family, community, corporation or a company. In small farming in Bangladesh, there are four main components of farm sector such as crops, livestock, fisheries and poultry.

The non-farm activities include all economic activities in rural areas except agriculture, livestock, forestry, fishing and hunting. Mostly manual labour based activities include self-employed subsistence-oriented cottage industries, wage employment in rural business activities, transport operation, and construction labour. Physical and human capital intensive activities include commercial type rural industries, including agro-processing, shop-keeping, peddling, petty trading; medium and large scale trading etc (LIFCHASA, 2012). Especially, the local NFS is defined as any earning activity that the workers are participating in within the village, other neighboring villages, growth centers or rural town while retaining the households in the village.

There are several reasons why the promotion of RNF activity can be of great interest to developing country's policy-makers. First, the evidence shows that RNF income is an important factor in household economies and therefore also in food security, since it allows greater access to food. Second, in the face of credit constraints, RNF activity affects the performance of agriculture by providing farmers with cash to invest in productivityenhancing inputs. Third, the nature and performance of agriculture, themselves affected by agricultural policies, can have important effects on the dynamism of the RNF activities to the extent that the latter is linked to agriculture. These activities grow fastest and most equitably where agriculture is dynamic (Reardon, 1998). Therefore, the importance of nonfarm sector is great to improve the socioeconomic status of the household. 
The people of haor areas have very little production assets and have no year round working opportunities to earn money for purchasing food and other daily necessities of life. As a result, they face hunger during lean period of work. They are mostly agricultural labourers, who suffer from food insecurity and high micro-nutrient deficiencies which results in consistently reduced productivity, loss of working days and various illnesses. These imbalances of human body can be reduced by producing more of the farm enterprises. Another way of increasing the income of haor people during slack period of work is to involve in various non-farm activities which will facilitate the households' to lead a good life.

A little information is available on both farm and non-farm sector's relative profitability patterns, the activities performed in both of the sectors, the market linkages involved in these sectors as well as the factors affecting the farm and non-farm income of haor inhabitants. Therefore, the present study is expected to add more information on this two sectors profitability patterns and its importance on socioeconomic factors affecting farm and non-farm income. The study would suggest the ways of increasing their incomes by involving in various non-farm activities that in turn would help to improve the livelihood of farming community in haor areas. The result of the study may also be helpful for the farmers in making right decisions regarding the selection of any profitable sector (farm or non-farm sector) which will ultimately help them to allocate their scarce resources accordingly.

Considering the above facts, the objectives of the present study is to document the socioeconomic characteristics and to identify the factors affecting the farm and non-farm incomes of the participating farmers.

\section{RESEARCH METHODS}

Considering the objectives, time, availability of fund and man power for conducting the present research, a two stage sampling procedure was followed. In the first stage, the Upazila namely Mohangonj under Netrokona district was selected purposively where multiple crops, livestock, poultry and fish catching of the different farming systems and also the different non-farm activities were practiced. In the second stage, the samples of 60 farmers were selected by simple random sampling procedure for obtaining the primary data for the study. In addition, the secondary data were collected from BBS, BARC, DAE, DoF, DLS, MoFL and MoA. Focus Group discussions (FGD) were conducted taking at least three from each of the selected group. The present study covered six months period from January to June, 2013.

To quantify the effects of explanatory variables on dependent variable there are some econometric models such as linear, semi log, log linear or double log model, etc. But these models are not equally applicable for all cases. In order to estimate the effects of socioeconomic variables on farm and non-farm income, Cobb-Douglas form of production function was chosen on the basis of a best fit and significant result on dependent variable. 
Many factors affect household income but it is not proper to include all the variables in a model due to theoretical and economic considerations. Here, five important variables were selected and care was also taken to avoid the multicollinearity of the selected variables. For estimating the effects of different variable on farm income and non-farm income, the log linear form of Cobb-Douglas production function is as follows:

1. $\ln \mathrm{Y}_{\mathrm{f}}=\mathrm{a}+\mathrm{b}_{1} \ln \mathrm{X}_{1}+\mathrm{b}_{2} \ln \mathrm{X}_{2}+\mathrm{b}_{3} \ln \mathrm{X}_{3}+\mathrm{b}_{4} \ln \mathrm{X}_{4}+\mathrm{b}_{5} \ln \mathrm{X}_{5}+\mathrm{U}_{\mathrm{i}}$

2. $\ln Y_{n f}=a+b_{1} \ln X_{1}+b_{2} \ln X_{2}+b_{3} \ln X_{3}+b_{4} \ln X_{4}+b_{5} \ln X_{5}+U_{i}$

Where, $Y_{\mathrm{f}}=$ Farm income $\left(\mathrm{Tk} . /\right.$ farm); $\mathrm{X}_{1}=$ Age of the respondents (years); $\mathrm{X}_{2}=$ Family size (total number of family members); $X_{3}=$ Farm size (acre); $X_{4}=$ Level of education (years of schoolings); $X_{5}=$ Non-farm income (Tk. /annum) for first model and Farm income (Tk. / farm) for the second model ; $a=$ Constant or intercept term; $b_{1}, b_{2}, b_{3}, b_{4}, b_{5}=$ Coefficients of the respective input variables; and $\mathrm{U}_{\mathrm{i}}=$ Stochastic disturbance/ error term.

\section{RESULTS AND DISCUSSION}

\section{Socioeconomic profile of respondents}

Socioeconomic background and characteristics of the respondents have a vital role in farm and non-farm activities to a great extent. In addition, these characteristics can be used as important indicators in making comparison among different categories of the respondents. A number of socioeconomic aspects of the sample households were examined. These were age, family size, farm size, occupational structure, educational attainment for the members of selected households, farm and non-farm income, employment opportunities etc. These characteristics are presented in Table 1.

It was found from the study that $80 \%$ of the farmers were middle aged (aged between 15 49 years) and had primary level of education (43.33\%). The average family size in that area was 6.07 which were higher than the national average of 4.53 (HIES, 2010) and the malefemale ratio was 1.18 . Besides farming boating $(8.33 \%)$, business $(6.67 \%)$, fish trading $(6.67 \%)$ and non-agricultural labour $(8.33 \%)$ were the dominant subsidiary occupations for the farmers. About $63 \%$ of the farmers were small whereas large farmers stood only $3.33 \%$ of total. The average farm size per household was 2.20 acre. Farm income of the respondents was higher which occupied $64.66 \%$ of the total household income than the non-farm income which occupied only $35.34 \%$ of their total household income.

\section{Factors affecting the level of farm and non-farm income}

The contribution of selected factors on farm and non-farm income can be examined from the individual regression co-efficient of each model. The results have been presented in Table 2 and interpretations have been illustrated accordingly which is discussed below.

Family size was measured by taking into consideration all the existing family members of the respondent households. In this study, family size was assumed to affect the households' farm and non-farm income. The regression coefficients of family size show 
that increase in family size would lead to increase in the farming status of the household. That means $1 \%$ increase in family size will increase the household's farm and non-farm income by $0.458 \%$ and $3.681 \%$ respectively. The results are expected because households in the study area have a perception that the addition of one working member in a family help to perform their farm and non-farm operations, hence, increase the farm production and expand the non-farm income earning activities which in turn may increase the probability of the household to increase their farm and non-farm income.

Table 1. Socioeconomic characteristic of sample households

\begin{tabular}{|c|c|c|c|}
\hline Variable & Class & Total No. of $\mathrm{HH}$ & $\%$ \\
\hline \multirow[t]{3}{*}{ Age distribution } & $<15$ & - & \\
\hline & $15-49$ & 48 & 80.00 \\
\hline & $>50$ & 12 & 20.00 \\
\hline Total & & 60 & 100.00 \\
\hline Mean age & & & 39.33 \\
\hline \multirow[t]{4}{*}{ Level of education } & Illiterate & 23 & 38.33 \\
\hline & Primary education & 26 & 43.33 \\
\hline & Secondary education & 10 & 16.67 \\
\hline & Higher education & 1 & 1.67 \\
\hline Total & & 60 & 100.00 \\
\hline Mean level of education & & & 3.31 \\
\hline \multicolumn{4}{|l|}{ Occupational pattern } \\
\hline \multirow[t]{7}{*}{ Main occupation } & Rice production & 23 & 38.33 \\
\hline & Rice production \& livestock production & 18 & 30.00 \\
\hline & Rice production \& fisheries production & 6 & 10.00 \\
\hline & Rice production \& non-rice crop production & 5 & 8.33 \\
\hline & Small business/shop keeping & 2 & 3.33 \\
\hline & Rice production \& agricultural wage labour & 2 & 3.33 \\
\hline & Non-agricultural wage labour & 4 & 6.67 \\
\hline Total & & 60 & 100.00 \\
\hline \multirow[t]{14}{*}{ Secondary occupation } & Boating & 5 & 8.33 \\
\hline & Service & 2 & 3.33 \\
\hline & Small business/shop keeping & 4 & 6.67 \\
\hline & Fish trading & 4 & 6.67 \\
\hline & Rice trading & 2 & 3.33 \\
\hline & Agricultural wage labour & 2 & 3.33 \\
\hline & Rice production & 3 & 5.00 \\
\hline & Non-agricultural wage labour & 5 & 8.33 \\
\hline & Open water fishing & 3 & 5.00 \\
\hline & Livestock production & 2 & 3.33 \\
\hline & Net repairing & 3 & 5.00 \\
\hline & Fisheries production & 3 & 5.00 \\
\hline & Others & 10 & 16.67 \\
\hline & Blank & 12 & 20.00 \\
\hline
\end{tabular}




\begin{tabular}{|c|c|c|c|}
\hline Variable & Class & Total No. of $\mathrm{HH}$ & $\%$ \\
\hline \multicolumn{2}{|l|}{ Total } & 60 & 60 \\
\hline \multirow[t]{3}{*}{ Family size } & Between 1-5 & 30 & 50.00 \\
\hline & Between 6-10 & 28 & 46.67 \\
\hline & Above 10 & 2 & 3.33 \\
\hline \multicolumn{2}{|l|}{ Total } & 60 & 100.00 \\
\hline \multicolumn{2}{|c|}{ Mean family size (No.) } & & 6.07 \\
\hline \multirow[t]{4}{*}{ Farm size } & Marginal (0.05-0.49 acres) & 3 & 5.00 \\
\hline & Small (0.50-2.49 acres) & 38 & 63.33 \\
\hline & Medium (2.50-7.49 acres) & 17 & 28.33 \\
\hline & Large (Above 7.50 acres) & 2 & 3.33 \\
\hline \multicolumn{2}{|l|}{ Total } & 60 & 100.00 \\
\hline \multicolumn{2}{|c|}{ Male: Female ratio } & & 1.18 \\
\hline \multicolumn{2}{|c|}{ Average farm size per household (acre) } & & 2.20 \\
\hline \multicolumn{2}{|c|}{ Farm and non-farm income } & & $\%$ \\
\hline \multicolumn{2}{|c|}{ Farm income (Tk.) } & 36715.19 & 64.66 \\
\hline \multicolumn{2}{|c|}{ Non-farm income (Tk.) } & 20066.67 & 35.34 \\
\hline \multicolumn{2}{|c|}{ Total household income (Tk.) } & 56781.86 & 100.00 \\
\hline
\end{tabular}

Source: Field Survey, 2013

Table 2. Estimated values of co-efficient and related statistics for measuring farm and nonfarm income

\begin{tabular}{l|c|c|c|c|c|c}
\hline \multicolumn{1}{c}{ Selected variables } & \multicolumn{3}{c|}{ Farm income } & \multicolumn{3}{c}{ Non-farm income } \\
\cline { 2 - 7 } & Coefficients & $\begin{array}{c}\text { Standard } \\
\text { error }\end{array}$ & t-value & Coefficients & $\begin{array}{c}\text { Standard } \\
\text { error }\end{array}$ & t-value \\
\hline Age & 0.085 & 0.261 & 0.327 & 0.378 & 2.588 & 0.146 \\
Family size & $0.485^{* *}$ & 0.201 & 2.415 & $3.681^{*}$ & 2.030 & 1.813 \\
Farm size & $0.275^{* * *}$ & 0.076 & 3.613 & 0.118 & 0.838 & 0.141 \\
Literacy level & -0.105 & 0.084 & -1.262 & 0.634 & 0.834 & 0.761 \\
Non-farm income & $-0.044^{* * *}$ & 0.012 & -3.545 & - & - & - \\
Farm income & - & - & - & $-4.297^{* * *}$ & 1.212 & -3.545 \\
\hline
\end{tabular}

Source: Author's estimation, 2013, Note: *,**,** indicate significant at $10 \%, 5 \%$ and $1 \%$ level respectively

It was assumed for the study that if the farm size increases, the total incomes would also increase. Here, the estimated regression coefficient of first model for farm size was 0.275 which was significant at $1 \%$ level of significance. It implies that holding all other variable constant, $1 \%$ increase in farm size would lead to an increase in the household's farm income by $0.275 \%$. For the second model, the estimated regression coefficient for farm size was 0.118 which was positive but not statistically significant. 
The variable $\left(\mathrm{X}_{5}\right)$ was considered as non-farm income while estimating the effects of different variables on farm income. Alternatively, it was considered as farm income while estimating the effects of different variables on non-farm income. It was measured by the annual average income (i.e. net return per household) earned by the household per farm and non-farm activities per unit. It was assumed that as the average farm and non-farm income increases separately in a family, total income would decrease for both sector. This result of first model implies that other things being equal, $1 \%$ increase in the level of nonfarm income decreases the probability of household to increase their farm income by $0.044 \%$. This could be expected because increased non-farm income may induce the farmers not to be engaged themselves in farm activities. This is because at present, the net return obtained from the farm sector is comparatively lower than the non-farm sector. On the other hand, the estimated result of the second model shows that $1 \%$ increased farm income decreases the probability of household to increase their non-farm income by $4.297 \%$. The results of first and second model imply that the assumption was true for both variables $\left(\mathrm{X}_{5}\right)$.

\section{CONCLUSION AND RECOMMENDATIONS}

The present study was an attempt to identify the socioeconomic characteristics of the farmers and the factors affecting the farm and non-farm incomes in a Haor economy. Based on the descriptive evidence emanating from this study, the following conclusions can be drawn on the findings:

- Most of the farmers were middle aged (aged between 15-49 years) and had primary level of education. The average family size was 6.07 which is comparatively higher than the national average of 4.53 (HIES, 2010).

- The number of small farmers was the highest in the study area. Besides farming boating, business, fish trading and non-agricultural labour were the dominant subsidiary occupations for the farmers. They got major portion of their income from the farm sources, but non-farm income also cover a part of their farm income and it was more profitable sector compared to the farm sector.

- The estimated results of the first model shows that family size and farm size had a positive effect on farm income and non-farm income had a negative but statistically significant effect on farm income.

- The estimated results of the second model shows that the effects family size had a positive effect on non-farm income and farm income had a negative but statistically significant effect on non-farm income.

With a view to promoting the farm and non-farm sector income and strengthening its potential linkages between them, the study mainly recommends increasing efforts on two fronts: first, reforming the institutions responsible for rural development and second, developing activities and projects that would enhance farm and non-farm linkages. 
In addition to the above recommendations, the following specific recommendations can be made.

$>$ For long-run benefit of the society interest free educational materials as well as other supports should be provided to the children of poor families so that they can go to the school rather than being illiterate and work in the fields.

$>$ Farmers should be encouraged to utilize their farm and farming resources accordingly so as to earn more benefit from farming.

$>$ Farmers should be encouraged to engage themselves in non-farm activities beside farm activities in order to sustain their farm sector income and to increase their standard of living in all rural areas, especially, the haor areas of Bangladesh.

$>$ Extension agents should provide information to the farmers about which sector is more profitable in terms of their income earning motive.

\section{REFERENCES}

Alam, M. S., Quayum, M. A. and Islam, M. A. 2011. Crop Production in the Haor Areas of Bangladesh: Insights from Farm Level Survey. A Scientific Journal of Krishi Foundation, 2010, 8(2), Agricultural Economics Division, Bangladesh Rice Research Institute, Gazipur1701, Bangladesh: 88-97. Email: msalam_07@yahoo.com

BER, 2012. Bangladesh Economic Review, Ministry of Finance, Government of the Peoples' Republic of Bangladesh, Dhaka.

BHWDB, 2011. Bangladesh Haor and Wetland Development Board. Ministry of Water Resources, Government of the People's Republic of Bangladesh, Dhaka. Email: http://www.cegisbd.com/pdf/HaorMasterPlan.pdf

Islam, S. 2012. An Economic Study on Different Farming Systems in Dingaputa Haor Area of Netrokona District. M.S. Thesis, Department of Agricultural Economics, Bangladesh Agricultural University, Mymensingh.

LIFCHASA, 2012. Livelihood Improvement of Farming Communities in Haor Areas through System Approach. Annual Report 2012, Department of Agronomy, Bangladesh Agricultural University, Mymensingh.

Reardon, T. 1998. Rural non farm income in developing countries. Paper prepared for FAO. Economic and Social Development Department, FAO Agricultural Series. Email: http:// www.fao.org 